\title{
China Offshore Wind Power Costs and Environmental Impact Analysis
}

\author{
Bo-yang SUN \\ School of Environment, Beijing Normal University, \\ Beijing, 100875, China \\ Jie-ting HUANG \\ China Renewable Energy Engineering Institute, No.2, \\ Beixiao St, Xicheng District \\ Beijing, 100875, China \\ e-mail: hjieting@gmail.com
}

\author{
Xiao-hua YANG* \\ School of Environment, Beijing Normal University, \\ Beijing, 100875, China \\ e-mail: xiaohuayang@bnu.edu.cn
}

\begin{abstract}
Offshore wind power is a strategic focus on new energy development, China's coastal areas have carried out large-scale offshore wind power development planning. At present, the UK is the world's largest offshore wind power market, with over 15 years of experience in offshore wind power. The British Government have a long -term cooperation with all the stakeholders of offshore wind power. And plans to make offshore wind power costs in 2020 fell to $£ 100$ / MWh. This paper analyzed the constraints and control measures on cost control for the UK offshore wind power and the leader's advanced experience and accumulated in actual project, combined with China's specific national conditions and environmental impact analysis, given the empirical and policy recommendations at this stage in China offshore wind power costs drop process.
\end{abstract}

Keywords-Offshore wind power; Cost-benefit analysis; Environmental impact.

\section{INTRODUCTION}

China is rich in offshore wind resources in coastal areas, power grid connection and consumptive in a better condition. Development and construction of offshore wind farms is an important part of China's wind power development. According to the "Thirteen Five Year Plan" of wind power development, wind capacity could reach 10 million kilowatts or more at the end of the "Thirteen Five Year Plan".

Offshore wind power in China is in its infancy. Offshore wind projects overall costs is higher than developed country. Due to a variety of factors (wind energy resources, construction conditions, post-maintenance and running costs), China's wind power offshore construction overall progress is slow. In contrast, the British offshore wind power experienced. Its installed capacity accounted for 53\% of all of Europe's total offshore wind power capacity, it is the world's largest offshore wind power market at present [1]. Under the UK government's leading, UK offshore wind power costs fell plan results are obvious. The plan makes the UK offshore wind power generation project standardization costs from 2010 to 2014 dropped by $11 \%$, and is expected to cost in 2020 reduced to $£ 100 /$ MWh [2]. (Figure 1)

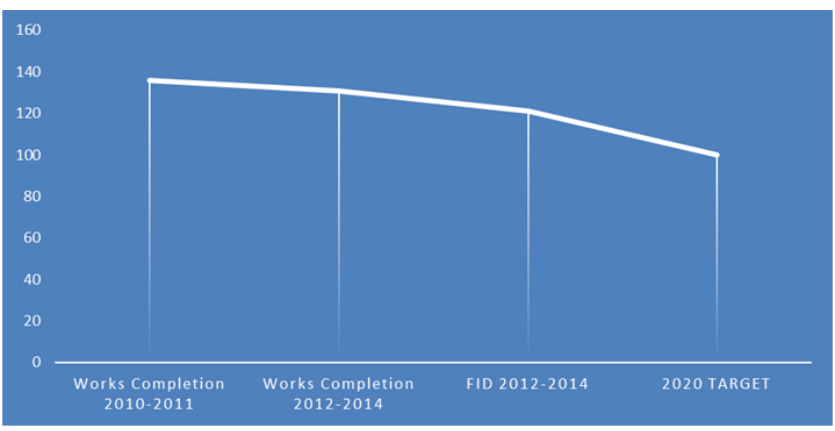

Figure 1. The track of UK offshore wind power costs down.

While the situation in Britain and China are not the same, but there are much in common between the two countries, this shows that the UK's experience is still a considerable reference for China. Therefore, listing and collation the offshore wind power cost control programs in UK, and combined with China's actual situation, it is possible to given a series of policy proposals for cost reduction in offshore wind power project.

\section{UK OFFSHORE WIND POWER COST ANALYSIS}

Britain has more than 15 years of experience in offshore wind power, its offshore wind power installed capacity ranks first in all of Europe, Germany and Denmark ranked second and third. Up to now, Britain is operating 27 offshore wind projects and the total installed capacity of 5.1GW (1452 wind turbines). Annual generating capacity reached $15 \mathrm{TWh}$, it accounted for $4.4 \%$ of the UK's electricity demand, and another $13 \mathrm{GW}$ of projects under construction or planned. July 2011, the British government through its renewable energy roadmap made clear in 2020 offshore wind power costs to $£ 100$ / MWh goals.

The implementation of CFD mechanism [3] is the cost of the UK offshore wind power project is a major decline in motivation. CFD refers to a legal agreement between low-carbon power generation side and carbon contract company. For the generation side the price difference is between strike price (The price of electricity generation through a particular low carbon technologies) and reference 
price (The average price on the UK market). By reducing the volatility is higher than the strike price is determined to ensure the stability and income of generation side, while protecting consumers from paying the high cost of support in times of high electricity prices. In addition, multi-party coordination mechanism established between the British government and the offshore wind industry in the UK is another motivation of the cost of offshore wind power project decreased. Including offshore wind power research led by the Royal Assets, CRTF, Offshore Wind Power Project Committee, etc. The above cost reduction coordination mechanisms have a large offshore wind power interests of the parties involved in, including offshore wind farm developers, owners, offshore wind turbine manufacturers, installers British waters, the key parts of equipment suppliers, port companies, transmission companies, industry consultants and key financial institutions and insurance companies. Overall, the United Kingdom has led through different government agencies to establish a number of highly coordinated, well-running offshore wind power cost reduction mechanism, to ensure the interests of all parties under the premise and effective contribute to the progressive decline in costs. Currently, the UK is through the use of more powerful fans, more large pile system, reduce project operation and maintenance costs, extend equipment life, the introduction of more effective financial mechanisms and improve the supply of other means to reduce the cost of the offshore wind power project.

\section{China OfFShORE WIND POWER COST ANALysis}

China's offshore wind power development started late, is in its infancy. By the end of 2013, national approval of offshore wind power project capacity is 2.22 million kilowatts, of which 390000 kilowatts have been built, mainly in Jiangsu Province and Shanghai, all of the projects have connected to the grid. 1.83 million kilowatts under construction, mainly distributed in Jiangsu, Shanghai and Zhejiang. In addition, Weifang, Shandong, Shanghai and Fujian Fuqing also have large-capacity wind turbine commissioning (5MW and 6MW). The end of July 2015, during the construction of offshore wind power development plan, 2 projects has been put into operation, 9 under construction, 6 to be built, total installed capacity of 3.303 million kilowatts.First, confirm that you have the correct template for your paper size. This template has been tailored for output on the US-letter paper size. If you are using A4-sized paper, please close this template and download the file for A4 paper format called "CPS A4 format".

Take Rudong intertidal wind farm as example, analysis the cost constituted of China's offshore wind power project. Jiangsu Rudong 150MW Intertidal Wind Farm investment of about 2.5 billion RMB, it is China's first offshore intertidal wind power demonstration project. The project is located in Rudong Harbour Bund, 4-10 km offshore, on June 21, 2011 officially started construction works, 2012 put into operation. As the unit into operation at different times, to reflect the operation of the entire project, using annual data of 2013 for cost analysis. The wind farm electricity generation in 2013 was about 400 million $\mathrm{kwh}$, annual utilization hours is about 2600 hours.

Rudong Intertidal offshore wind farms initial investment consists of the following components: equipment purchase, construction and installation costs, other costs, construction period interest and reserve funds and the like. Each part cost of total investment is different, impact on the cost of power generation are not the same. Equipment purchase costs account for about $43 \%$ of the project cost, greater impact on costs. the wind turbine and tower costs account for $75 \%$ of the cost of equipment, single kilowatt costs about $6350 \mathrm{RMB}$, greater impact on the overall cost of the equipment, the submarine cable take about $12 \%$ of the cost of equipment, cost about 1,000 RMB per kW. Construction and installation cost $45 \%$ of the total cost about $8750 \mathrm{RMB} / \mathrm{kW}$. Relative to onshore wind, offshore wind power construction and installation cost of the total cost than the major. This is mainly due to the completion of the currently small number of offshore wind farm projects, small-scale, corresponding ship machine equipment immaturity, lack of experience in construction. Other costs include items with a sea land costs, ecological compensation, project construction and management fees, production preparation fees, the total cost of about $12.44 \%$, the cost per $\mathrm{kW}$ of about $1500 \mathrm{RMB} / \mathrm{kW}$. Ecological compensation which accounted for about half. Ecological compensation fee is mainly used for the protection of birds and fish near the project. Such as the construction of new habitat and protection facilities. Construction of the wind farm construction period interest and interest related to the total cost of about $4.5 \%$. Interest on the run do not belong to the initial investment, but accounted for a larger proportion of operating costs, the interest rate adjustment will have a greater impact on the cost of electricity. Overall, the impact of wind farms on interest costs have a greater uncertainty. Equipment of Rudong intertidal offshore wind farms to be maintained include wind turbine equipment, booster station equipment and platforms, the submarine cable and the like. Take into account the big waves caused by typhoon and code wave, wind turbine operation and maintenance will be more difficult and high maintenance costs. Currently the equipment of the project during its life cycle the reliability is gradually decline, repair costs need to be considered in stages, in the construction period and the warranty period take $0.5 \%$ of the value of fixed assets, other years take $1.5 \%$. But with the increased reliability of wind turbines, the development of offshore construction vessels technology, is expected to reduce the maritime operation and maintenance costs to a certain extent in the future.

\section{ChinA AND THE United KINGDOM OFFSHORE Wind COST COMPARISON}

\section{A. Project Initial Investment and Environmental Impact}

In order to clarify the drivers of China offshore wind power cost reduction, drawing on British successful experience to explore the decline in China's offshore wind power cost path, boosting China offshore wind power industry development, comparative analysis of the 
similarities and differences between China and UK offshore wind power project investment levels and cost structure is very important. UK offshore wind capital expenditure including contingency budget and technical capital expenditure, excluding transactions and project finance, insurance and land rent, not including maritime transmission costs, these costs are borne by the offshore transmission owner (OFTO). UK offshore wind capital expenditures have linear relationship with the depth and distance from the shore, so the water depth and distance from shore are the main factors that lead to increased investment costs. Rudong intertidal offshore wind power project in comparison with the UK offshore wind power project cost shown in Figure 2.

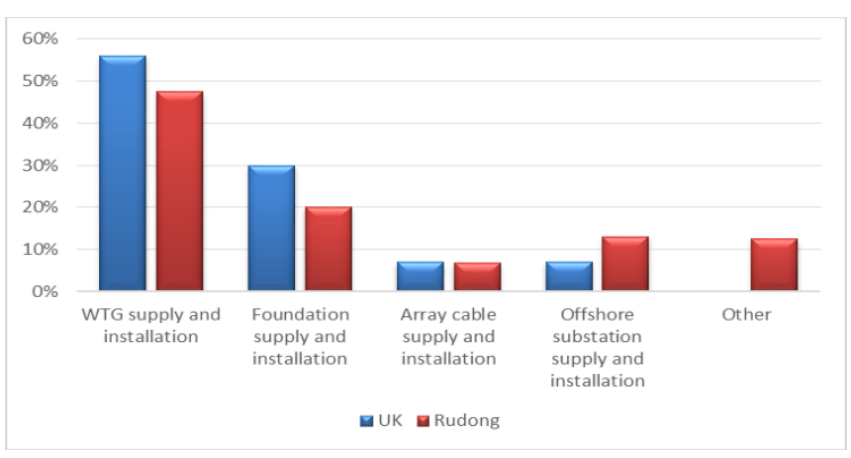

Figure 2. Offshore wind power project cost structure comparison chart

Figure 2 shows in both UK and China offshore wind power project capital expenditures, wind turbines account for a large proportion, nearly $50 \%$. UK offshore wind turbine foundation supply and installation take $30 \%$ of the total cost, in Rudong the proportion is $20.2 \%$. UK offshore wind collector lines supply and installation take $7 \%$ of the total cost, such as $6.83 \%$ in Rudong. The cost of China and the UK offshore wind farm collector lines is closer. It is noteworthy that, in Rudong intertidal offshore wind power other charges constitute the 12.44 percent of total costs (Other costs include costs of construction land by the sea, fisheries and marine resources compensation, fee for use sea, across cable compensation fees, terminal rental fees), but the UK wind power project cost structure does not include such costs, this resulting in high cost of offshore wind power in China.

\section{B. Analysis of Project Operation and Maintenance Costs}

UK offshore wind power operating costs primarily include wind turbine maintenance, technical operations and management, auxiliary equipment maintenance, decommissioning preparation, insurance, operating costs, and other expenses, Wind turbine maintenance costs account for over $50 \%$ of operating costs, administrative costs depends on project size, complexity of the wind farm, as well as operation and maintenance experience. Operating costs have no obvious correlation with project capacity and water depth, But linear correlation with distance from shore, the farther the distance from shore, the higher operating costs. During the UK offshore wind farm operators, developers are required to pay fees to use the grid, namely TNUoS, including pan-regional electricity generation tax, local lines tax, local substations taxes. TNUoS vary over time and location, it depends on the electricity market, electricity demand and offshore transmission owner (OFTO) income level.

At present, there is lack of China offshore wind power operational data. Now estimated Rudong intertidal demonstration wind farm operation and maintenance costs, the first 1-5 years the operation and maintenance costs amounted to 34.4 million RMB, in 6-10 years the operation and maintenance costs amounted to 43.65 million RMB, the in 11-20 years the operation and maintenance costs amounted to 48.4 million RMB, in 21-25 years the operation and maintenance costs amounted to 53.15 million RMB, the average of 25 years operation period is 45.6 million RMB per year and 300,000 RMB / MW.

\section{CONCLUSION}

China's government attaches great importance to the development of offshore wind power, but the overall development is relatively slow. The initial investment and post operating cost in the project remains high. In contrast, the British offshore wind power started earlier and the good momentum of development. By analyzing China offshore wind power project and compare with the UK similar project we can see that, it has similar expenditure structure of offshore wind power project investment between the two countries, but the Chinese offshore wind power project investment accounted for a large proportion of other expenses, resulting in other non-technical expenses overburdened. Recommend that China should improve the project operation and maintenance, supporting policies, technological innovation, add new investment and financing channels, set up a government-led, multi-stakeholder coordination mechanisms involved in the control of local costs of offshore wind power projects, and promote the healthy development of the industry.

\section{ACKNOWLEDGMENT}

This work is supported by State Key Laboratory of Earth Surface Processes and Resource Ecology. This work was supported by the Project of National Natural Foundation of China (No.51079004, 51379013), and the State Key Program of National Natural Science of China (No. 41530635).

\section{REFERENCES}

[1] UK Renewable Energy Roadmap (2011), https://www.gov.uk/government/uploads/system/uploads/attachment_ data/file/48128/2167-uk-renewable-energy-roadmap.pdf.

[2] Cost Reduction Monitoring Framework (2015), http://www.thecrownestate.co.uk/media/451533/owpb-ore-catapult-c ost-reduction-monitoring-report.pdf.

[3] Electricity Market Reform: Contracts for Difference (2015), https://www.gov.uk/government/collections/electricity-market-reform -contracts-for-difference.

[4] UK Government White Paper, licensed under the Open Government License v1.0 (2011). 